\title{
Trilhas de Ìmalè: reflexões sobre o percurso criativo do espetáculo İmalè Inú Yàgbà e de seus simbolismos em cena
}

\section{Adnã lonara Maria Alves*, Mariana Baruco Machado Andraus}

\section{Resumo}

Este projeto teve como objetivo refletir acerca do processo de criação do espetáculo solo İmalè Inú Yàgbà, elaborado como Trabalho de Conclusão do Curso Bacharelado em Dança, durante o ano de 2017, a partir dos simbolismos utilizados na cena e em perspectiva estética. A pesquisa de Iniciação Científica pretendeu aprofundar o estudo dos referenciais teóricos que embasaram a criação do espetáculo e discutir a dramaturgia resultante da concepção do trabalho revertendo em pesquisa teórica. A partir do mergulho nos materiais investigados ao longo do processo criativo, intentou-se voltar o olhar, em retrospecto, para os simbolismos utilizados e seus subtextos, a fim de promover uma reflexão teórica e analítica do discurso corporal tecido e, assim, produzir um trabalho que possibilite o entrelaçamento entre criação artística e alicerces teóricos em artes da cena.

\section{Palavras-chave:}

Dança; ancestralidade; memória

\section{Introdução}

Ímalè Inú Yàgbà, espetáculo elaborado ao final da disciplina de Trabalho de Conclusão do Curso Bacharelado em Dança, do Departamento de Artes Corporais da Unicamp, foi elaborado sob orientação da Profa. Dra. Mariana Baruco Machado Andraus e apresentado ao longo do mês de novembro de 2017. A partir das investigações, tomando por base memórias pessoais e coletivas enquanto mulher negra em sociedade, o trabalho se debruça sobre o mito iorubá das Grandes Mães Ancestrais e a sensibilidade dos contos literários da escritora Conceição Evaristo, bem como sobre a proposta pluricultural de dança-arteeducação da Profa. Dra. Inaicyra Falcão dos Santos, também intitulada "Corpo e Ancestralidade", construindo um discurso pautado em corpo, condição e experiência, a fim de reportar a dimensão subjetiva do existir negro e suas escrevivências. Sendo assim, projeto teve como escopo refletir a partir dos simbolismos utilizados na cena e em perspectiva estética o processo de criação do espetáculo İmalè Inú Yàgbà. Discutindo, em retrospecto as escolhas assumidas em cena e seus subtextos na tentativa de promover um trabalho cientifico capaz de possibilitar pensares interseccionados em criação artístico e firmamentos teóricos da dança.

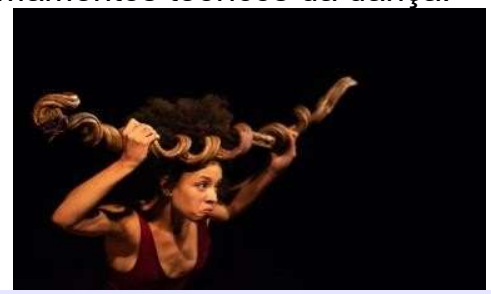

\section{Resultados e Discussão}

A transmissão do mito e das memórias pessoais e coletivas investigadas no espetáculo deu-se por meio das práticas, sejam elas lendo livros e ou contos, por oralidade em longas conversas com a minha avó e mãe, minhas àgbás (senhoras mais velhas), exercícios práticos de rememorização das reminiscências na tentativa de verbalizá-las através do corpo, ou mesmo na execução de laboratórios improvisacionais e até mesmo na própria efemeridade da cena. Assim, a construção da memória neste trabalho deu-se de forma coletiva, isto é, construída socialmente e sua corporificação estabelecida nas ações do dançar. A pesquisa e análise da obra levaram ao levantamento de 4 camadas de simbólicas: 01) Interior Sagrado: Concepção; 02) Cajado: Despertar e estruturação; 03) Mulher: Bicho-passagem; 04). A edificação do corpo.

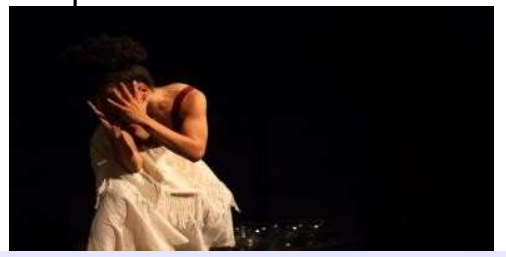

Conclusão

Além de discorrer sobre os simbolismos escolhidos e explorados em cena e seus possíveis significados e subtextos, a presente pesquisa objetivou refletir e discorrer sobre a necessidade do reconhecimento das "Danças Negras" (Danças Negras, aqui, lida como conceito) enquanto campo de conhecimento na área da Dança. A dança, assim como todas as manifestações de corpos negros em diáspora, comunica um movimento de construção identitária: ela circunda as experiências negras e as disseminações de seus saberes empreendidos, ao passo que suporta uma "cicatriz" histórica causada pelas chagas da escravização e da branquitude.

\section{Agradecimentos}

Ao Programa de Iniciação Científica da Unicamp, ao $\mathrm{CNPQ} / \mathrm{SAE}$, à minha orientadora Mariana Andraus, aos amigos ímpares nesta pesquisa, José Teixeira, Milena Pereira, Graciela Soares, Eduardo Scaramuzza, Otis Selimane, Alessandra Guedes, Pedro Picelli, Pedro Assunção e às docentes e aos funcionários do Departamento de Artes Corporais.

BOSI, Ecléa. Memória e sociedade: lembranças de velhos. $3^{\text {a }}$ edição. São Paulo: Companhia das Letras, 1994.

FERRAZ, Fernando Marques Camargo. Danças Negras: entre apagamentos e afirmação no cenário político das artes. Revista Eixo, v. 6, n. 2

(Especial). p. 115-124. Brasília, Nov. 2017..

SANTOS, Inaicyra Falcão dos. Corpo e Ancestralidade: uma proposta pluricultural de dança-arte-educação. $2^{\mathrm{a}}$ edição. São Paulo: Terceira Margem, 2014 . 